\title{
Matrix Metalloproteinase-9 Is Essential for Physiological Beta Cell Function and Islet Vascularization in Adult Mice
}

\author{
Gustaf Christoffersson, ${ }^{*}$ Tomas Waldén, ${ }^{*}$ Monica Sandberg, ${ }^{*}$ Ghislain Opdenakker, ${ }^{\dagger}$ Per-Ola Carlsson, ${ }^{* \dagger}$ and Mia Phillipson*
}

From the Departments of Medical Cell Biology* and Medical Sciences, ${ }^{\ddagger}$ Uppsala University, Uppsala, Sweden; and the Department of Microbiology and Immunology, ${ }^{\dagger}$ Rega Institute for Medical Research, University of Leuven, KU Leuven, Leuven, Belgium

Accepted for publication

December 22, 2014

Address correspondence to Mia Phillipson, Ph.D.,

Department of Medical Cell Biology, Uppsala University, PO Box 571, 75123 Uppsala, Sweden. E-mail: mia.

phillipson@mcb.uu.se.

\begin{abstract}
The availability of paracrine factors in the islets of Langerhans, and the constitution of the beta cell basement membrane can both be affected by proteolytic enzymes. This study aimed to investigate the effects of the extracellular matrix-degrading enzyme gelatinase B/matrix metalloproteinase- 9 (Mmp-9) on islet function in mice. Islet function of $M m p 9$-deficient $\left(\mathrm{Mmp9}^{-/-}\right)$mice and their wild-type littermates was evaluated both in vivo and in vitro. The pancreata of $M m p 9^{-/-}$mice did not differ from wild type in islet mass or distribution. However, $\mathrm{Mmp9}^{-/-}$mice had an impaired response to a glucose load in vivo, with lower serum insulin levels. The glucose-stimulated insulin secretion was reduced also in vitro in isolated $M m p 9^{-/-}$islets. The vascular density of $M m p 9^{-/-}$islets was lower, and the capillaries had fewer fenestrations, whereas the islet blood flow was threefold higher. These alterations could partly be explained by compensatory changes in the expression of matrix-related proteins. This in-depth investigation of the effects of the loss of MMP-9 function on pancreatic islets uncovers a deteriorated beta cell function that is primarily due to a shift in the beta cell phenotype, but also due to islet vascular aberrations. This likely reflects the importance of a normal islet matrix turnover exerted by MMP-9, and concomitant release of paracrine factors sequestered on the matrix. (Am J Pathol 2015, 185: 1094-1103; http://dx.doi.org/10.1016/j.ajpath.2014.12.009)
\end{abstract}

The presence of matrix metalloproteinases in pancreatic islets was described more than 15 years ago, ${ }^{1,2}$ but their exact role for islet function has still not been determined. Some of these enzymes have been implicated as important in pancreas development and islet morphogenesis, 3,4 whereas other reports indicate that, at least, the most studied metalloproteinases, matrix metalloproteinase-2 (MMP-2) and MMP-9 are dispensable in this aspect. Proteinases hold the potential to affect the morphology and function of pancreatic islets not only by direct effects, but preferentially by regulating the availability of different growth factors and chemokines bound to the extracellular matrix. ${ }^{6,7}$ Thus, the predominant proangiogenic effect of MMP-9 is mediated by the release of vascular endothelial growth factor A (VEGF-A) from macromolecules during matrix degradation, which turns VEGF-A accessible as a mitogen for endothelial cells. ${ }^{8}$ Indeed, MMP-9 has been implicated as a key player in the angiogenic shift during development of islet tumors, as well as in revascularization of transplanted pancreatic islets..$^{8-10}$

The importance of the islet vasculature for the endocrine function of the pancreatic islets has gained considerable interest in recent years. The islets are among the best bloodperfused organs in the body, ${ }^{11,12}$ where each beta cell is in

Supported by the Swedish Research Council (M.P. and P.-O.C.), the Swedish Diabetes Fund (Diabetesfonden) (M.P., P.-O.C., and G.C.), the Swedish national strategic research initiative EXODIAB (Excellence of Diabetes Research in Sweden) awarded to Uppsala and Lund Universities, Diabetes Wellness Sweden (M.P. and P.-O.C.), the Ragnar Söderberg Foundation (M.P.), the Knut and Alice Wallenberg Foundation (M.P.), the Swedish Diabetes Foundation (Svenska Diabetesstiftelsen) (G.C.), the Family Ernfors Foundation (M.P.), the Novo Nordisk Foundation (M.P. and P.-O.C.), the Fund for Scientific Research of Flanders (FWO-Vlaanderen) (G.O.), and the Geconcerteerde OnderzoeksActies (GOA 2013/014) in Belgium (G.O.).

P.-O.C. and M.P. contributed equally as senior authors.

Disclosures: None declared. 
direct contact with at least one endothelial cell. ${ }^{13}$ Thus, the endothelial cells are constantly interacting with the endocrine cells through paracrine influence, ${ }^{14}$ and several endothelial cell-derived factors such as laminins, ${ }^{15,16}$ thrombospondin- $1,{ }^{17}$ and hepatocyte growth factor ${ }^{18}$ have been shown to be of importance for beta cell function, differentiation, and proliferation in the adult.

The high level of tortuous vascularization of the islets is due to the release of VEGF-A from beta cells, and mice incapable of beta cell synthesis of VEGF-A exhibit markedly decreased islet capillary density, as well as nonoptimal blood glucose control in the adult. ${ }^{19}$ The maintained release of VEGF-A from beta cells is of importance also during adulthood to preserve the high level of vascularization as well as keeping the microvascular endothelium in a highly fenestrated state. ${ }^{20,21}$ Genetic interference with the VEGF-A gene in beta cells in the adult mouse will not affect islet mass or insulin secretion in vitro, but rather will affect the islet endothelium to reduce fenestration and thereby delay insulin release. ${ }^{20}$

Here, we tested the hypothesis that MMP-9 plays a critical role in beta-cell function and islet vascular homeostasis in postnatal islets. This was addressed in Mmp9-deficient $\left(\mathrm{Mmp}^{-/-}\right)$mice by both in vivo and in vitro experiments to be able to discriminate between alterations of the beta-cell phenotype and indirect effects on blood glucose homeostasis mediated by vascular changes, ie, alterations in vascular density, blood perfusion, or capillary fenestrations.

\section{Materials and Methods}

Animals

Male $\mathrm{Mmp}^{-1-}$ mice, ${ }^{22}$ backcrossed 12 generations to C57Bl/6 and their wild-type (WT) littermates (25 to $30 \mathrm{~g}$; Rega Institute, Leuven, Belgium), at 3 to 6 months of age had free access to tap water and pelleted food throughout the study. All experiments were approved by the Uppsala Regional Laboratory Animal Ethics Committee.

\section{Glucose Tolerance Tests}

Glucose [2.5 g/kg body weight (b.w.); Fresenius-Kabi, Uppsala, Sweden] was injected i.p. into the mice, and plasma glucose concentrations were measured before injection, and at 15, 30, 60, and 120 minutes after injection using blood glucose reagent strips (FreeStyle, Abbott, Alameda, CA).

\section{Insulin Tolerance Tests}

Insulin aspart (2 U/kg b.w.; NovoRapid; Novo Nordisk, Bagsvaerd, Denmark) was injected i.p., and plasma glucose levels were determined immediately before and 15, 30, 60, $90,120,180,240$, and 300 minutes after injection using blood glucose reagent strips.

\section{Islet Endocrine Mass and Vascular Density}

Pancreata from WT and $M m p 9^{-/-}$mice were retrieved, weighed, fixed in $10 \%(\mathrm{v} / \mathrm{v})$ formaldehyde, and embedded in paraffin. Sections ( $5 \mu \mathrm{m}$ thick) of the pancreata were stained with a guinea pig antibody for insulin (ICN Biomedicals, Aurora, $\mathrm{OH}),{ }^{23}$ and counterstained with hematoxylin. Some of the sections were also stained for endothelium with the lectin Bandeiraea simplicifolia-1 (BS-1; Sigma-Aldrich, St. Louis, MO) ${ }^{23}$ From each animal, $\geq 5$ tissue sections were systematically assessed to reflect all parts of the pancreas. The fraction of the pancreas that was composed of endocrine tissue was measured by a direct point-counting method ${ }^{24}$ and used for calculation of the endocrine mass compensating for differences in pancreatic weight between animals. Islet vascular numbers were also counted in a microscope. The area of the investigated islets was determined using ImageJ software version $1.49 \mathrm{~g}$ (NIH, Bethesda, MD).

\section{Islet Isolation and Culture}

Pancreatic islets from WT and $M m p 9^{-1-}$ mice were isolated using a collagenase digestion protocol, ${ }^{25}$ and maintained free floating in groups of 150 islets at $37^{\circ} \mathrm{C}$ (air/carbon dioxide, 95:5) overnight in $5 \mathrm{~mL}$ of tissue culture medium composed of RPMI1640 medium supplemented with 2 $\mathrm{mmol} / \mathrm{L} \mathrm{L}$-glutamine, $11.1 \mathrm{mmol} / \mathrm{L}$ glucose, and $10 \%(\mathrm{v} / \mathrm{v})$ fetal calf serum before the islet function assays ( $c f$. below).

\section{Glucose-Stimulated Insulin Release}

After 3 to 4 days of culture, groups of 10 islets, from WT and from $M m p 9^{-1-}$ mice, were transferred to vials containing Krebs-Ringer bicarbonate buffer supplemented with 10 $\mathrm{mmol} / \mathrm{L}$ HEPES, $3 \mathrm{mg} / \mathrm{mL}$ bovine serum albumin (ICN Biomedicals, Santa Ana, CA), and $10 \mathrm{mmol} / \mathrm{L}$ glucosamine; hereafter referred to as KRBH buffer. The KRBH buffer contained $1.67 \mathrm{mmol} / \mathrm{L}$ D-glucose during the first hour of incubation at $37^{\circ} \mathrm{C}$ (oxygen/carbon dioxide, 95:5). The medium was then removed and replaced by KRBH supplemented with $16.7 \mathrm{mmol} / \mathrm{L}$ glucose and the islets were then incubated for a second hour. After this second incubation, the islets were harvested, following retrieval of the medium, and homogenized by sonication in $200 \mu \mathrm{L}$ of redistilled water. A fraction of the homogenate was mixed with acid-ethanol [0.18 $\mathrm{mol} / \mathrm{L} \mathrm{HCl}$ in $95 \%$ (v/v) ethanol] from which insulin was extracted overnight. Thus, these measurements were performed after exposure to both low and high glucose in all islets. Insulin contents in incubation media and homogenates were determined by a mouse insulin enzyme-linked immunosorbent assay kit (Mercodia AB, Uppsala, Sweden).

\section{(Pro)insulin Biosynthesis}

Duplicate groups of 10 isolated islets from WT and $M m p 9^{-/-}$ mice were size matched and incubated for 120 minutes in 100 
$\mu \mathrm{L}$ of KRBH supplemented with $2 \mathrm{mg} / \mathrm{mL}$ bovine serum albumin, $16.7 \mathrm{mmol} / \mathrm{L}$ glucose, and $\mathrm{L}-\left[4,5{ }^{3} \mathrm{H}\right]$ leucine to measure the incorporation of tritiated leucine during (pro)insulin and total protein biosynthesis. Assays were performed as described previously. ${ }^{16}$

\section{Glucose 0xidation}

Duplicate groups of 10 isolated islets from WT and $M m p 9^{-/-}$ mice were size matched, incubated in $100 \mu \mathrm{L}$ of KRBH supplemented with $\mathrm{D}-\left[\mathrm{U}_{-}{ }^{14} \mathrm{C}\right]$ glucose and nonradioactive glucose to give a high $(16.7 \mathrm{mmol} / \mathrm{L})$ glucose concentration. The vials containing the islets were incubated for 90 minutes in a slow-shaking water bath at $37^{\circ} \mathrm{C}$ before the glucose oxidation was terminated with $100 \mu \mathrm{L}$ of $0.05 \mathrm{mmol} / \mathrm{L}$ antimycin A (Sigma-Aldrich). Additionally $100 \mu \mathrm{L}$ of 0.4 $\mathrm{mol} / \mathrm{L} \mathrm{Na}_{2} \mathrm{HPO}_{4}$ (pH 6.0) was injected to release the carbon dioxide formed. The carbon dixode was trapped by the addition of Hyamine 10-X (New England Nuclear, Boston, MA) before another incubation period of 120 minutes at $37^{\circ} \mathrm{C}$. Scintillation fluid (Ultima Gold, PerkinElmer, Waltham, MA) was added, and the radioactivity was measured in a liquid scintillation counter. The glucose oxidation rates were used as a measure of mitochondrial function. ${ }^{16}$

\section{Diabetes Induction Model}

Mice were injected i.p. with $40 \mathrm{mg} / \mathrm{kg}$ streptozotocin (SigmaAldrich) in citrate buffer on five consecutive days in a multiple low-dose streptozotocin (MLDS) protocol. ${ }^{26}$ Blood glucose was monitored every third day using blood glucose reagent strips.

\section{Islet Gene Expression}

Total RNA was isolated from freshly isolated islets and with RNeasy Micro Plus kit (Qiagen, Hilden, Germany). The quality of the mRNA as measured by the absorbance ratio at $260 \mathrm{~nm}$ and $280 \mathrm{~nm}$ (NanoDrop; Thermo Fischer, Wilmington, DE) was above 1.85 for all samples. Conversion of RNA into complementary DNA was performed with the High Capacity cDNA kit (Life Technologies Europe, Stockholm, Sweden). Custom-ordered TaqMan Array Micro Fluidic Cards (exon-spanning probes were used when available) were run on an Applied Biosystems 7E900HT Fast Real Time PCR system (Foster City, CA). The gene expression was profiled through the comparative $\mathrm{C}_{\mathrm{T}}$ method of relative quantification, with investigated genes (Supplemental Table S1) analyzed according to the manufacturer's instructions. $\beta$-Actin served as the reference gene.

\section{Histology}

Sections of formalin-fixed, paraffin-embedded mouse pancreata were stained using antibodies against VEGF-A (clone EP1176Y; Abcam, Cambridge, UK), collagen 4 (rabbit polyclonal, Abcam), laminin a5 (rabbit polyclonal, Abcam), and laminin $\beta 2$ (rabbit polyclonal; Novus Biologicals, Littleton, $\mathrm{CO})$. Glycoproteins in the islets were stained by using the periodic acid-Schiff method. Staining intensity was assessed in $200 \times$ magnification micrographs using ImageJ software.

\section{Transmission Electron Microscopy}

For islet endothelial cell morphology and islet microvascular density, pancreata from WT and $M m p 9^{-/-}$mice were cut into small pieces and fixed in $2 \%$ glutaraldehyde and $1 \%$ paraformaldehyde. These were embedded in Agar 100 epoxy resin (Oxford Instruments, Stockholm, Sweden). Ultrathin sections (50 to $60 \mathrm{~nm}$ ) were contrasted with uranyl acetate and lead citrate. Electron microscopy was performed using a FEI Tecnai G2 (Hillsboro, OR) transmission electron microscope at an accelerating voltage of $80 \mathrm{kV}$.

\section{Islet Blood Flow}

Mice were anesthetized by i.p. injections of avertin [2.5\% (v/v) solution of 2,2,2-tribromoethanol (Sigma-Aldrich) in 2-methyl2-butanol (Kemila, Stockholm, Sweden)] and placed on a heating pad to maintain body temperature. Animals were tracheostomized to facilitate respiration. Polyethylene catheters were inserted into the right carotid artery for blood pressure measurements and in the left femoral artery for blood sampling.

After a 15-minute resting period, blood flow measurements were performed using a microsphere technique as previously described. ${ }^{27}$ Briefly, approximately $1.5 \times 10^{5}$ black nonradioactive microspheres $(10-\mu \mathrm{m}$ diameter; Triton microspheres, San Diego, CA) were injected through the carotid catheter during 5 seconds. For a total of 60 seconds, arterial blood was collected by free flow from the catheter in the femoral artery. The exact withdrawal rate was confirmed by weighing the sample. The pancreas, both adrenal glands, and samples (approximately 40 $\mathrm{mg}$ each) from the colon, duodenum, and kidney were removed and weighed. The number of microspheres in the samples, including pancreatic islets was counted as previously described after visualization of islet microspheres by a freeze-thawing technique. ${ }^{28}$ The total number of islets and the total number of perfused islets were counted. Organ blood flow values were calculated according to the formula $\mathrm{Q}_{\text {org }}=\mathrm{Q}_{\text {ref }} \times N_{\text {org }} / N_{\text {ref }}$ where $\mathrm{Q}_{\text {org }}$ is the organ blood flow, $\mathrm{Q}_{\text {ref }}$ is withdrawal rate of the reference sample, $N_{\text {org }}$ is the number of microspheres in the organ, and $N_{\text {ref }}$ is the number of microspheres in the reference sample. The organ blood flow was expressed as milliliters per minute per gram tissue, whereas the islet perfusion was expressed as microliters per minute per gram pancreas. Adequate mixing of microspheres in the circulation was confirmed by comparing the blood flow values of the adrenal glands, which had to vary at most $10 \%$ within each animal.

\section{Statistics}

Values are expressed as mean \pm SEM. Unpaired two-tailed $t$-tests or analysis of variance repeated measures were used 
for comparison between groups. $P<0.05$ was considered as statistically significant.

\section{Results}

\section{Glucose Intolerance in Mmp-9-Deficient Mice}

As previously described, ${ }^{29}$ nonfasting blood glucose concentrations did not differ between $M m p 9^{-1-}$ mice and WT mice (time 0 min) (Figure 1A). However, an i.p. glucose tolerance test revealed that the $\mathrm{Mmp}^{9^{--}}$mice had an impaired response to the glucose load (Figure 1A), which resulted in an increased area under the curve of plasma glucose values during the 120 minutes test (Figure 1B).

\section{The Delayed Insulin Response in $\mathrm{Mmp9}^{-{ }^{--}}$Mice Is Islet-Related}

To determine whether the delayed glucose handling in the $M m p 9^{-1-}$ mice was related to islet defects or peripheral insulin resistance, peak insulin values during the i.p. glucose load were investigated and i.p. insulin tolerance tests were performed. When analyzing the serum insulin levels of the mice at the peak of insulin release (15 minutes) during the glucose tolerance test, the $\mathrm{Mmp}^{-{ }^{-1}}$ mice had lower levels of insulin (Figure 1C). By contrast, the response to the insulin challenge was similar in both genotypes (Figure 1D).

\section{The Morphology of Islets in Mmp-9-Deficient Mice Is Unchanged}

$M m p 9^{-/-}$have been shown to have a defect in their growth plates, ${ }^{30}$ resulting in slight growth retardation and smaller body size (Supplemental Table S2 $2^{31-42}$ ). The size of the pancreas in relation to the total body weight was, however, unaffected by the gelatinase deficiency (WT versus $\mathrm{Mmp}^{9^{-/}}$; $0.96 \pm 0.06 \%$ versus $0.86 \pm 0.02 \%$ pancreas weight of total b.w., $P=0.14)$. Matrix-degrading enzymes have also been postulated to affect migration of tissue cells during embryonal development, which may affect islet distribution and development. In the histological examination of pancreata from WT and $M m p 9^{-/-}$mice, we observed no difference in islet mass (Figure 1E), and a normal distribution of islets in the pancreas (Figure 1, F and G).

\section{Impaired Glucose-Stimulated Insulin Release from Mmp-9-Deficient Islets in Vitro}

Because no reduction in islet mass could be observed, we investigated whether the defective insulin secretion of $M m p 9^{-1-}$ mice in vivo remained in vitro, which would
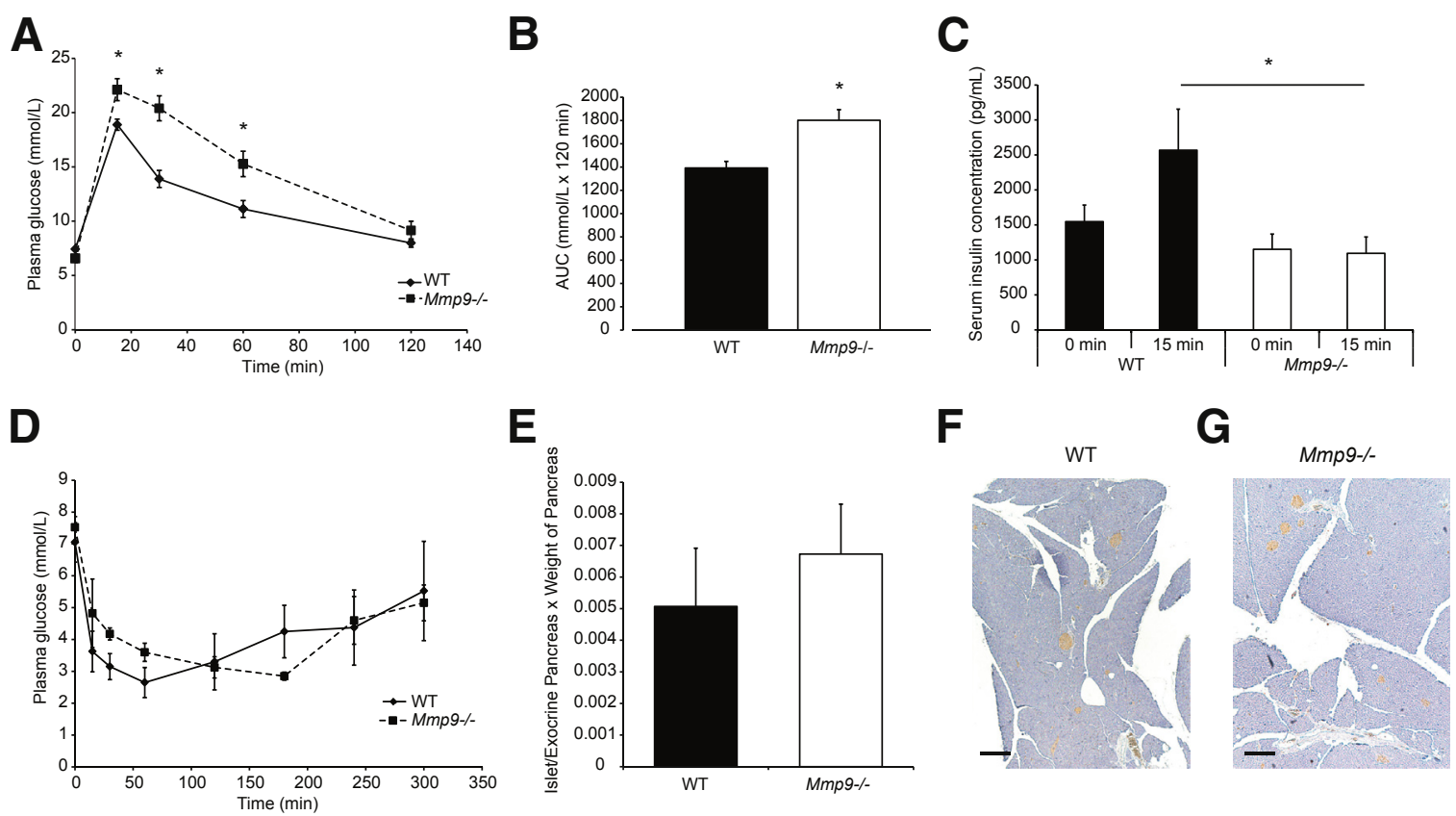

Figure 1 Deficiency of matrix metalloproteinase-9 (Mmp-9) results in a delayed response to glucose in mice. A and $\mathbf{B}: \mathbf{M m p}^{-/-}$mice have a delayed response to an i.p. glucose load $(2.5 \mathrm{~g} / \mathrm{kg} \mathrm{b.w.)} \mathrm{compared} \mathrm{to} \mathrm{WT} \mathrm{littermates,} \mathrm{resulting} \mathrm{in} \mathrm{an} \mathrm{increased} \mathrm{area} \mathrm{under} \mathrm{the} \mathrm{curve} \mathrm{(B).} \mathrm{C:} \mathrm{The} \mathrm{delay} \mathrm{in} \mathrm{the}$ response to the glucose load is related to an impaired insulin release as measured by the serum insulin concentration 15 minutes after an i.p. glucose load. D: This difference in glucose uptake is not due to peripheral insulin intolerance because an i.p. insulin tolerance test (2 U/kg b.w.) shows no differences between the genotypes. E: The decreased insulin secretion in the $M m p 9^{-1-}$ mice is not due to a decreased beta cell mass, as shown by histological examination of pancreatic tissue. F and G: Representative low-power magnification micrographs of insulin-stained pancreata from WT and $M m p 9^{-1-}$ mice, respectively. $n=8$ (B and C, mice per genotype); $n=7$ (D, mice per genotype); $n=5$ (E, mice per genotype); $n \geq 5$ tissue sections per pancreas (E, tissue sections per pancreas). ${ }^{\star} P<0.05(\mathbf{A}-\mathbf{C})$. Scale bars: $100 \mu \mathrm{m}(\mathbf{F}$ and $\mathbf{G})$. Original magnification $\times 25(\mathbf{F}$ and $\mathbf{G})$. AUC, area under the curve. 
indicate a change in beta-cell phenotype. Indeed, islets from $M m p 9^{-/-}$mice exhibited an impaired insulin release in response to a high glucose concentration when compared to islets of WT mice (Figure 2A). However, the content of insulin in the islets was similar in both the genotypes (Figure 2B), and so was glucose-stimulated (pro)insulin biosynthesis (Figure 2C), which indicate that the insulinproducing machinery was intact in $M m p 9^{-/-}$islets. Moreover, the mitochondrial function seemed normal, because the glucose oxidation rate did not differ between the genotypes (Figure 2D).

Mmp $9^{-/-}$Mice Are More Susceptible to MLDS Diabetes MMP-9 has previously been suggested to be involved in development of diabetes. ${ }^{43,44}$ The multiple low-dose streptozotocin (MLDS) protocol is a way of mimicking an autoimmune destruction of the islets of Langerhans occurring during onset of type 1 diabetes. ${ }^{26,29}$ Mice of both genotypes were subjected to this protocol, and their blood glucose levels were monitored for 51 days. In our hands, this protocol gave mild diabetes with a slow onset. The blood glucose levels of the $M m p 9^{-/-}$mice were slightly, but consistently higher than the WT mice, and differed significantly on 5 of 14 measuring points after the induction period (Figure 2E).

\section{Abnormal Islet Gene and Protein Expression in $\mathrm{Mmp9}^{-/-}$Mice}

The islet-related differences between the two genotypes led us to investigate the expression of a number of genes related to glucose-sensing, glucose metabolism, insulin exocytosis, and vascular components of possible paracrine importance for the beta cells (Supplemental Table S1). The islets from the two genotypes did not differ in most of the assayed genes related to glucose metabolism and sensing. However, the mRNA levels of two proteins, lactate dehydrogenase A (LDH-A) and peroxisome proliferator-activated receptor gamma, coactivator 1 beta $(\operatorname{PPAR} \gamma \mathrm{C} 1 \beta)$, were increased in the $\mathrm{Mmp}^{-1-}$ (Figure 3A). Also, the mRNA for tryptophan hydroxylase 1 (Tph1) involved in serotonin synthesis, and islet amyloid polypeptide (Iapp) were increased in the $M m p 9^{-/-}$islets (Figure 3). A number of genes coupled to islet vascularity were assessed, and among these, the mRNA expression of two laminins (Lama5 and Lamb2), and plasminogen activator inhibitor 1 (Serpine1)
A

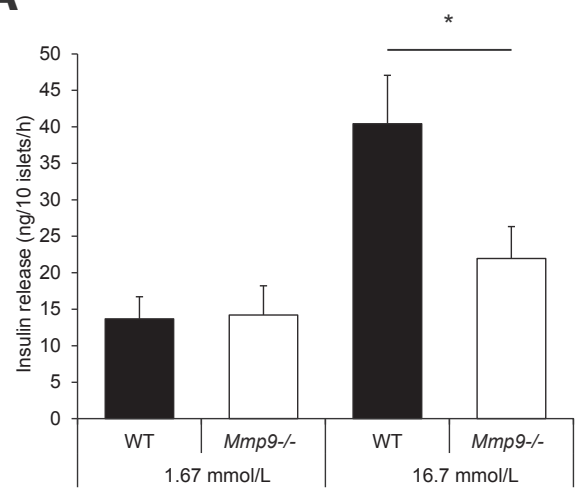

D

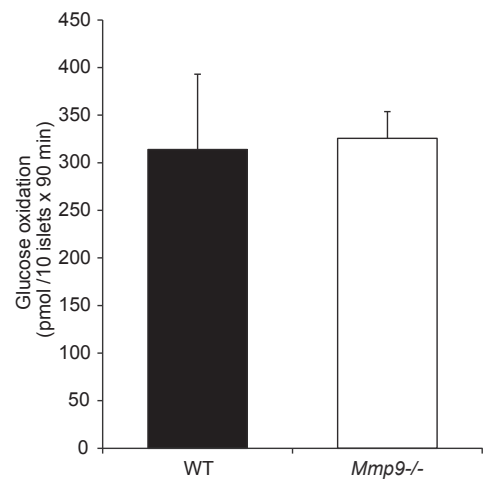

B

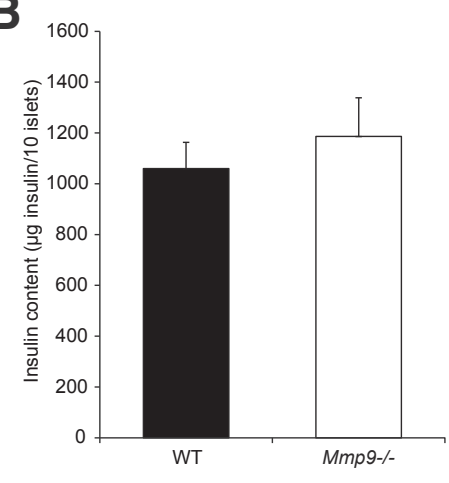

E

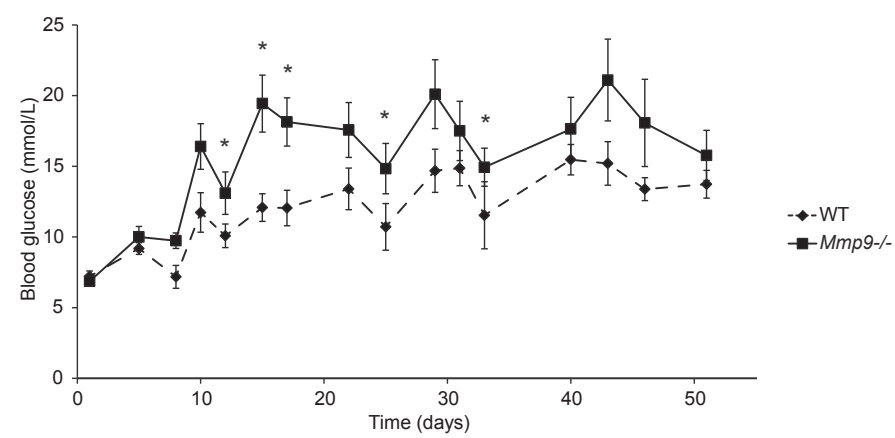

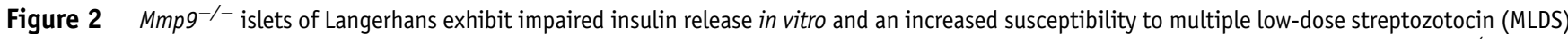
diabetes in vivo. Isolated pancreatic islets were assessed in vitro to determine the origin of the impaired response to glucose. A: Islets from $M m p 9^{-/-}$show a decreased release of insulin in response to an increased glucose concentration $(16.7 \mathrm{mmol} / \mathrm{L}$ versus $1.67 \mathrm{mmol} / \mathrm{L})$ in the medium. B-D: However, insulin content of these islets is not different (B), as is neither the synthesis of (pro)insulin (C), nor the oxidation of glucose in the beta cells (D). E: In multiple lowdose streptozotocin treatments of mice, $\mathrm{Mmp}^{9^{-/}}$mice are more susceptible to developing a more severe diabetes than their WT littermates. $n=5$ (A, mice per genotype); $n=6$ (E, mice per genotype). ${ }^{\star} P<0.05$. 
A

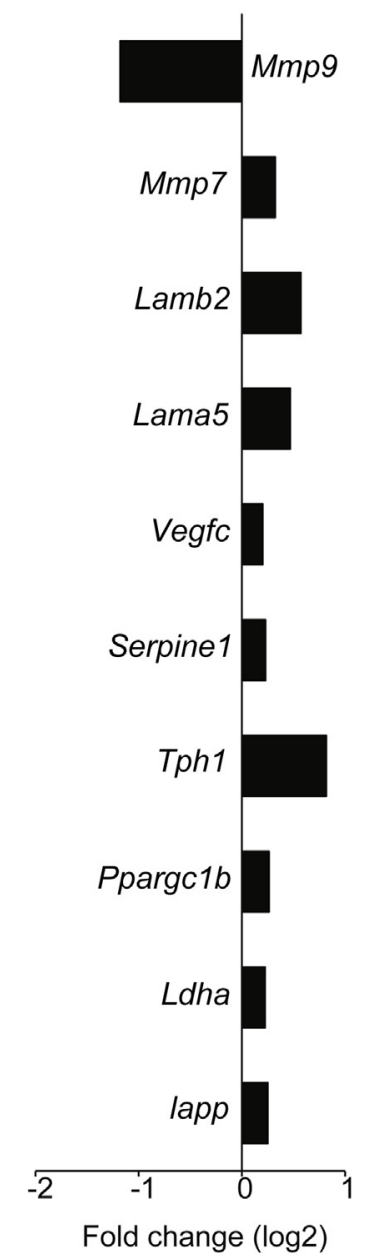

B
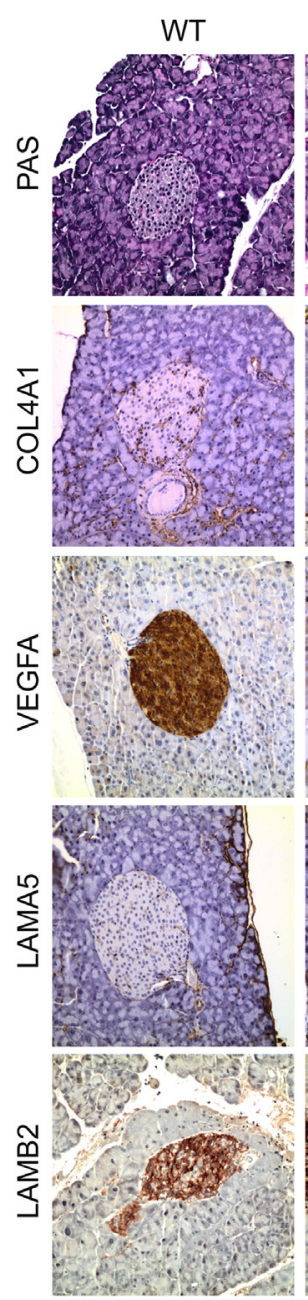

Mmp9-/-
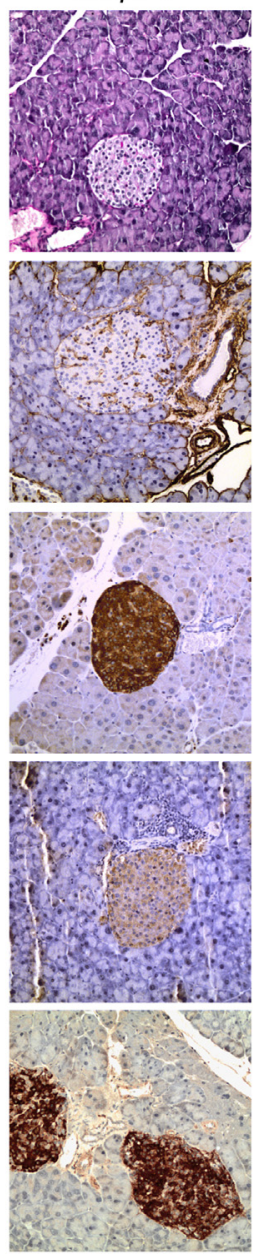

C

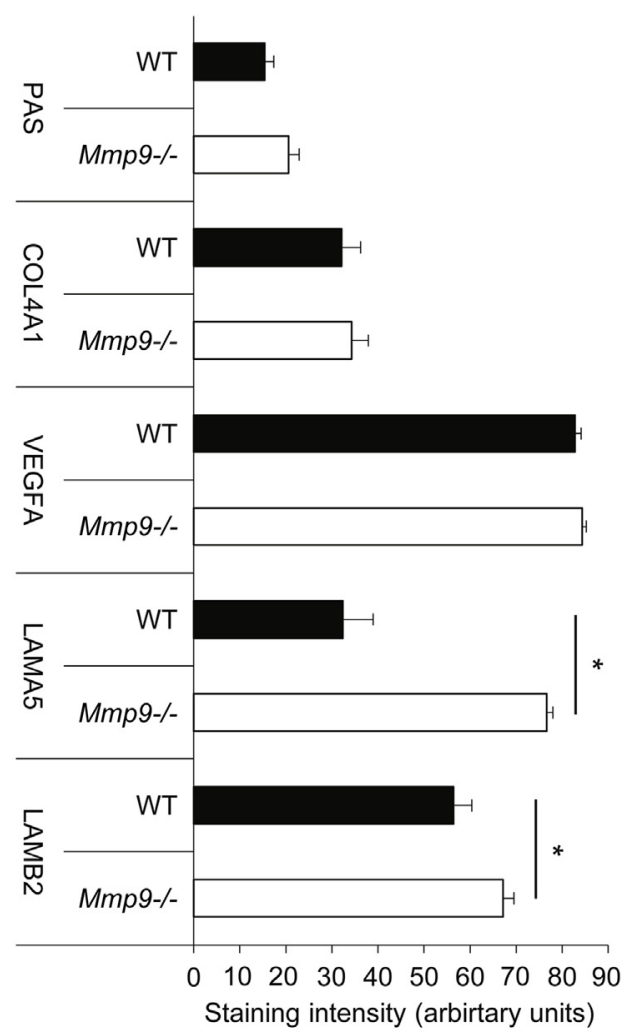

Figure $3 \mathrm{Mmp9}^{-/-}$pancreatic islets reveal compensatory transcriptional regulation at the gene and protein levels. The gene expression profile of whole $\mathrm{Mmp}^{-/-}$islets compared with WT islets, as determined by mRNA arrays ( $n=5$ mice per genotype). Genes related to the vasculature, the extracellular matrix, and beta cell metabolism are differently expressed. A: Genes that were detected with significantly different expression levels. Supplemental Table S1 lists all genes assessed and $2^{-\Delta \Delta \mathrm{Ct}}$ values. B: An IHC analysis of proteins related to the extracellular matrix was performed with the periodic acid-Schiff method. There are no differences in the amount of glycoproteins in the islets, or collagen IV, or VEGF-A present in the islets. The expressions of the matrix proteins laminin $\alpha 5$ and laminin $\beta 2$ are, however, significantly increased in $M m p 9^{-/-}$islets. C: Staining intensities are quantified. $n=5$ (C, mice per genotype). ${ }^{*} P<0.05$.

were augmented in $\mathrm{Mmp}^{-/-}$islets (Figure 3A). The expressions of laminin $\alpha 5$ and laminin $\beta 2$ were also shown to be increased on the protein level in immunohistochemical staining (Figure 3, B and C). Other matrix-related staining (periodic acid-Schiff and collagen IV) did not show any difference between the genotypes. Moreover, matrix metalloproteinase-7 (Mmp7) was upregulated in the $M m p 9^{-1-}$ mice (Figure 3A). The vascular endothelial growth factor C (Vegfc) mRNA was also increased in Mmp9 gene knockout mice (Figure 3A). All other genes that were assessed did not differ significantly between the genotypes.

\section{Aberrant Vascular Morphology in $\mathrm{Mmp9}^{-/-}$Islets}

MMP-9 is known as a major contributor to angiogenesis. ${ }^{8}$ The intra-islet vascular densities of the $\mathrm{Mmp}^{-/-}$mice were slightly decreased with regard to those found in WT mice (Figure 4A). When the ultrastructure of the capillary endothelial cells in the islets was studied by transmission electron microscopy, approximately $40 \%$ less fenestrae were observed in the $M m p 9^{-/-}$islets when compared to WT islets (Figure 4, B-F). These observations might suggest that the availability of VEGF-A is disturbed, ie, more VEGF-A is sequestered on the ECM. Anti-VEGF-A immunohistochemical staining, however, did not show any difference in staining intensity (Figure 3, B and C). The matrix degrading effect of MMP-9 could theoretically also influence and diminish the basement membrane between the beta cell and the endothelial cell, but no such effects were found when investigating islets by transmission electron microscopy. MMP-9 has also been implicated in the recruitment of pericytes to tumor microvasculature, ${ }^{45}$ possibly affecting vascular stability and function. However, anti-NG-2 staining 

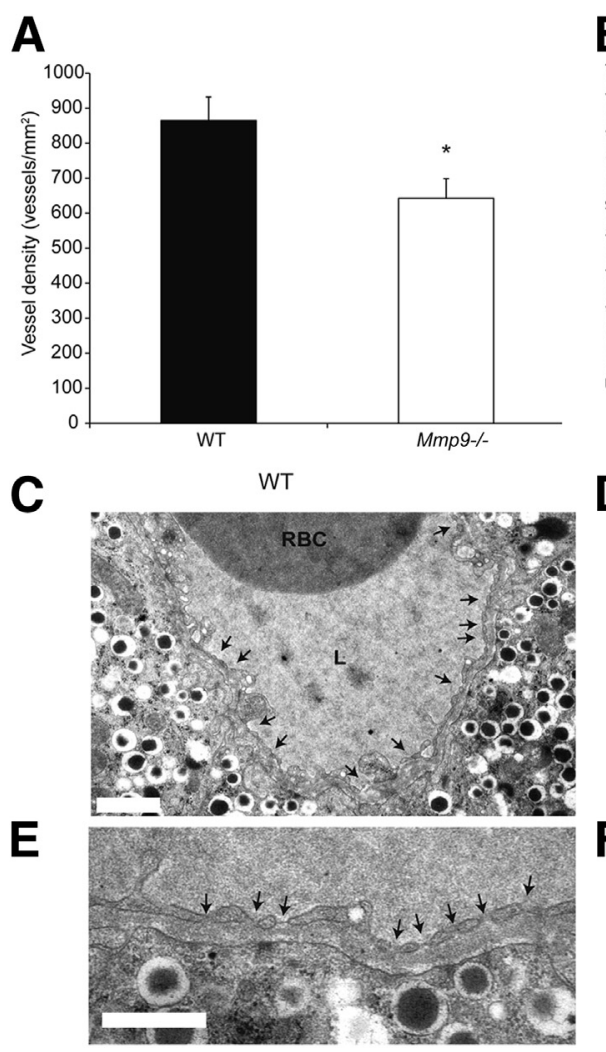

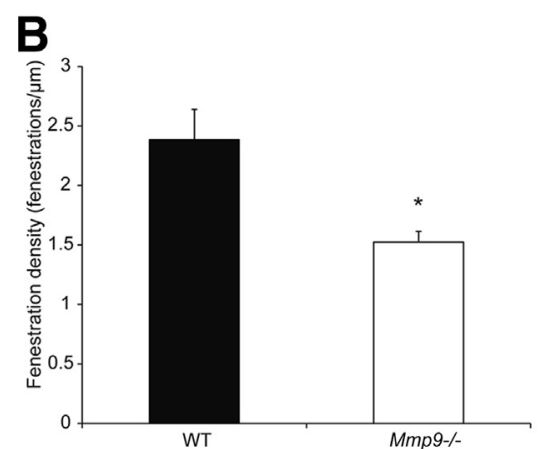

D

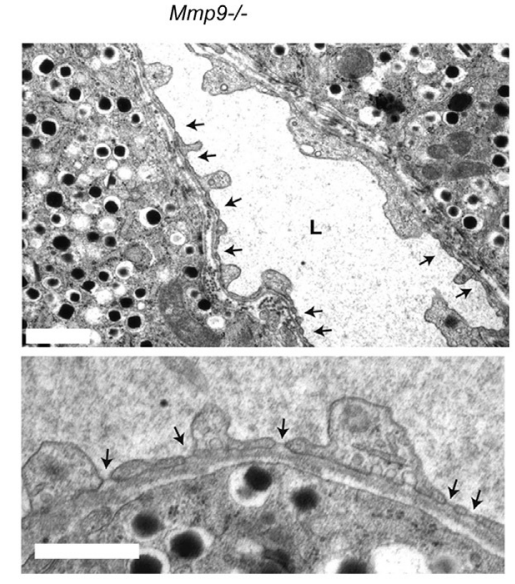

Figure $4 \mathrm{Mmp9}^{-/-}$mice have aberrant pancreatic islet vasculature and an increased islet blood flow. Matrix metalloproteinase-9 (Mmp-9) is an angiogenic enzyme, but is redundant in the $M m p 9^{-/-}$mouse. A: However, in pancreatic islets, a slight decrease in intra-islet vascular density is seen in tissue sections. B-F: $M m p 9^{-/-}$mice have significantly fewer fenestrations in the islet capillaries (B) as seen in transmission electron microscopy images $(\mathbf{C}-\mathbf{F})$ of the islet vasculature. Arrows indicate fenestrae. G: The effect of $M m p 9$ gene deletion on the islet blood flow was assessed by the microsphere technique. A threefold increase in blood flow in the $\mathrm{Mmp9}^{-/-}$islets is observed. $n=5(\mathbf{A}, \mathbf{C}-\mathbf{F}$, mice per genotype); $n \geq 5$ (A, $\mathbf{C}-\mathbf{F}$, tissue sections per pancreas). ${ }^{*} P<0.05$. Scale bars: $0.5 \mu \mathrm{m}(\mathbf{C}-\mathbf{F})$. $L$, lumen; RBC, red blood cell.

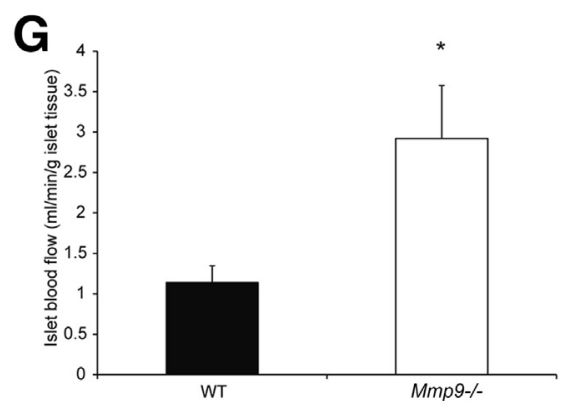

of pancreatic sections revealed normal pericyte coverage in the islets of $\mathrm{Mmp}^{-1-}$ mice (data not shown).

\section{Blood Flow Is Markedly Increased in $\mathrm{Mmp}^{-/-}$Islets}

Blood flow in pancreatic islets is normally tightly regulated and related to the sensing of glucose and the release of insulin by the beta cells. We investigated the impact of the detected vascular aberrations in the $\mathrm{Mmp}^{-/-}$islet capillaries for islet blood perfusion using the microsphere technique. Although the baseline blood glucose values, as well as mean arterial blood pressure (data not shown) were similar in the WT and $M m p 9^{-/-}$mice, the islet blood flow in the $\mathrm{Mmp}^{-1-}$ mice was increased approximately threefold at baseline conditions (Figure 4G).

\section{Discussion}

The matrix-degrading enzyme gelatinase B/MMP-9 has a multitude of functions in development and homeostasis, as well as in different pathologies. ${ }^{6,7}$ Here, we investigated the enigmatic role of this enzyme on the function of pancreatic islets. $M m p 9^{-1-}$ mice were shown to have an impaired insulin response to a glucose load. This impairment was found to depend on a change in beta cell phenotype, because $\mathrm{Mmp}^{9^{-/-}}$ islets exhibited a defective insulin secretion in response to a glucose challenge both in vivo and in vitro. With the use of gene array studies we were able to demonstrate significant changes in a number of pancreatic marker molecules, which were induced by the gene deletion. Moreover, substantial structural and functional changes in the islet vasculature were observed in $M m p 9^{-/-}$mice.

The role of the islet matrix for beta cell function has not yet been extensively studied. However, components of the islet basement membrane such as laminins, ${ }^{15,16}$ as well as components of, or molecules sequestered on the islet matrix, eg, heparan sulfate ${ }^{46}$ and thrombospondin- $1^{17}$ have been reported to be of high importance for support of beta cell differentiation, function, and proliferation. Moreover, VEGF-A, which is secreted by the beta cells and important for islet vascular maintenance and phenotype, is to a large proportion bound to the islet matrix. The depletion of MMP-9 most certainly decreases the islet matrix turnover, and thereby reduces the availability of immobilized molecules, such as growth factors. Indeed, the loss of MMP-9 function was accompanied by a decreased islet vascularization, and a marked reduction in the numbers of fenestrae in the capillaries. This finding indicates a lowered availability of the betacell-secreted VEGF-A for the islet endothelium in $M m p 9^{-/-}$ mice. Because the VEGF-A expression per se was not altered, this effect might be related to the previously described action of MMP-9 to release VEGF-A from the extracellular matrix. We were not, however, able to see any difference in the amount of VEGF-A sequestered in the islets using an immunohistochemical method. Because the islets are expressing 
VEGF-A at high levels already at the normal state, a difference might be difficult to be demonstrated with this approach. Nevertheless, in contrast to the studies with selectively reduced VEGF availability by interference at the transcriptional level, ${ }^{20,47}$ we observed concomitant changes in beta cell phenotype. This suggests that a normal islet matrix turnover is important, not only to maintain islet vascularity, but also for beta cell function in response to a glucose challenge.

A faulty insulin release machinery would cause delayed insulin secretion in response to glucose. However, we could not see any alterations at the transcriptional level of proteins previously described to be involved in insulin exocytosis, ${ }^{48}$ eg, Syntaxin 1A, Syntaxin 4A, and Snap25 in the $M m p 9^{-1-}$ islets. In addition, functional tests did not reveal any defects in the (pro)insulin biosynthesis nor in the mitochondria (the latter assessed by glucose oxidation rates). However, up-regulation of Ppargclb and Ldha in $M m p 9^{-/-}$islets indicate induction of non-oxidative glucose metabolism. ${ }^{49}$ Up-regulation of lactate dehydrogenase A has previously been shown to perturb the normal glucose sensing of the beta cell, resulting in a deteriorated glucose-stimulated insulin secretion response. ${ }^{50,51}$

Tryptophan hydroxylase-1 (TPH-1) is important both for insulin secretion by serotonylation of GTPases ${ }^{52}$ and for beta cell mass expansion during pregnancy. ${ }^{53}$ The observed up-regulated expression of Tphl in $M m p 9^{-/-}$mice would, therefore, seem paradoxical, but may reflect positive effects of a lowered islet matrix turnover or be a compensatory phenomenon. Also, Iapp was up-regulated in $M m p 9^{-/-}$ mice. MMP-9 has been implicated in the degradation of human IAPP (islet amyloid polypeptide ${ }^{43}$ ), which may suggest that the Iapp up-regulation was a compensatory phenomenon. However, IAPP per se seems to have mild or no physiological importance for islet function. ${ }^{54.55}$

In addition, MMP-9 in the pancreatic islet may cleave and release components in the vascular basement membrane of importance for the beta cells. We therefore first hypothesized that the basement membrane would be thickened by the lack of MMP-9, but ultrastructural examination of the islet capillaries revealed that this was not the case. Noteworthy, the gene expression of $M m p 7$ was up-regulated, and this proteinase and others might have compensated, at least partly, for the lack of MMP-9. Nevertheless, small differences in protease activity may influence the turnover and accumulation of MMP-9-substrates such as collagen IV and laminins. In fact, we observed an increased expression of two laminin genes (Lama5 and Lamb2), congruent with an unbalanced turnover in the basement membrane.

Of note, several of the genes that were found to be upregulated in the $\mathrm{Mmp}^{-/-}$islets are well-known substrates to MMP-9. Serpins, ${ }^{56,57}$ laminins, ${ }^{58,59}$ and IAPP ${ }^{43}$ are cleaved by this enzyme, and cleavage products from LDH-A have also been found in cell supernatants following MMP-9 activity. ${ }^{60}$ This suggests a direct link between the gene deletion and the compensatory changes in gene expression.
Islet blood flow is normally high and tightly regulated to meet the metabolic demands for insulin secretion at any time. ${ }^{12,61}$ Despite a lower vascular density, we recorded a threefold higher islet blood flow in $\mathrm{Mmp}^{-/-}$islets when compared to WT islets at baseline conditions, ie, at similar plasma glucose values. This may reflect a compensatory phenomenon for the lower vascular density with a blood flow increase mediated by ATP metabolites at a condition with a less optimal oxygen transport to tissue. ${ }^{62}$

The up-regulation of MMP-9 in the pancreas has been demonstrated to be a diabetogenic factor in human pancreatitis $^{63}$ and in experimental models of diabetes. ${ }^{29}$ Moreover, increased circulating concentrations of MMP-9 can be measured in type 1 diabetic patients. ${ }^{64}$ However, $\mathrm{Mmp}^{-/-}$ mice in the present study were observed to have a paradoxically increased susceptibility to MLDS diabetes. This might be due to the impaired beta cell function of $\mathrm{Mmp}^{9^{-/}}$ mice observed already during basal conditions. Moreover, the threefold higher blood perfusion of $M m p 9^{-/-}$islets would be expected to increase the delivery of streptozotocin to these islets thereby increasing their vulnerability.

Previous studies of the influence of MMP-9 on pancreas physiology did not address the development and function of the normal mouse pancreas or any compensation mechanism by the gene deletion. In addition, the normal development of mouse pancreas has been studied ${ }^{5}$ and, also in that study, compensation mechanisms were not yet discovered. ${ }^{5}$ In the current study, the observed alterations were made in a nonleaky Mmp9 knockout mouse and are reflecting convincingly true compensatory mechanisms (Supplemental Table S2). The changes seen in this study are not based on tissue reorganization by an acute insult, but rather are the result of homeostatic long-term events. Therefore, our data are also relevant for those future studies in which long-term MMP-9 inhibition will be used. It will be critical to monitor glycemia, diabetes induction, and eventually, islet blood flow changes in such studies.

In conclusion, this study presents an in-depth investigation of the effects of the loss of MMP-9 function on the islets of Langerhans and complements previous work..$^{5} \mathrm{~A}$ deteriorated beta cell function was observed, primarily as a result of a shift in the beta cell phenotype, but also because of islet vascular aberrations. These effects are likely to reflect the importance of a normal islet matrix turnover exerted by MMP-9, and concomitant release and proteolysis of paracrine signaling proteins sequestered on the matrix.

\section{Acknowledgments}

We thank Birgitta Bodin, Ing-Britt Hallgren, Astrid Nordin, Malin Olsen, Zhanchun Li (Uppsala University, Sweden), and Anders Ahlander (SciLifeLab, Uppsala University) for skilled technical assistance; Greet Thijs (Rega Institute for Medical Research, University of Leuven, Belgium) for 
excellent care for the backcrosses and maintenance of the $M m p 9^{-/-}$mouse colonies.

G.C. designed experiments, performed research, analyzed data, and wrote the manuscript; T.W. performed research and analyzed data; M.S. performed research; G.O. contributed mice and to the discussion of the results and writing the manuscript; P.-O.C. initiated the study, designed experiments, and wrote the manuscript; M.P. designed experiments, analyzed data, wrote the manuscript, and supervised the research project. All authors revised the manuscript critically for intellectual content and approved the final version of the paper.

\section{Supplemental Data}

Supplemental material for this article can be found at http://dx.doi.org/10.1016/j.ajpath.2014.12.009.

\section{References}

1. Tomita T, Iwata K: Gelatinases and inhibitors of gelatinases in pancreatic islets and islet cell tumors. Mod Pathol 1997, 10:47-54

2. Barro C, Zaoui P, Morel F, Benhamou PY: Matrix metalloproteinase expression in rat pancreatic islets. Pancreas 1998, 17:378-382

3. Miralles F, Battelino T, Czernichow P, Scharfmann R: TGF-beta plays a key role in morphogenesis of the pancreatic islets of Langerhans by controlling the activity of the matrix metalloproteinase MMP-2. J Cell Biol 1998, 143:827-836

4. Miettinen PJ, Huotari M, Koivisto T, Ustinov J, Palgi J, Rasilainen S, Lehtonen E, Keski-Oja J, Otonkoski T: Impaired migration and delayed differentiation of pancreatic islet cells in mice lacking EGFreceptors. Development 2000, 127:2617-2627

5. Perez SE, Cano DA, Dao-Pick T, Rougier JP, Werb Z, Hebrok M: Matrix metalloproteinases 2 and 9 are dispensable for pancreatic islet formation and function in vivo. Diabetes 2005, $54: 694-701$

6. Van den Steen PE, Dubois B, Nelissen I, Rudd PM, Dwek RA, Opdenakker G: Biochemistry and molecular biology of gelatinase B or matrix metalloproteinase-9 (MMP-9). Crit Rev Biochem Mol Biol 2002, 37:375-536

7. Vandooren J, Van den Steen PE, Opdenakker G: Biochemistry and molecular biology of gelatinase B or matrix metalloproteinase-9 (MMP-9): the next decade. Crit Rev Biochem Mol Biol 2013, 48: 222-272

8. Bergers G, Brekken R, McMahon G, Vu TH, Itoh T, Tamaki K, Tanzawa K, Thorpe P, Itohara S, Werb Z, Hanahan D: Matrix metalloproteinase- 9 triggers the angiogenic switch during carcinogenesis. Nat Cell Biol 2000, 2:737-744

9. Olsson R, Maxhuni A, Carlsson PO: Revascularization of transplanted pancreatic islets following culture with stimulators of angiogenesis. Transplantation 2006, 82:340-347

10. Christoffersson G, Vagesjo E, Vandooren J, Liden M, Massena S, Reinert RB, Brissova M, Powers AC, Opdenakker G, Phillipson M: VEGF-A recruits a proangiogenic MMP-9-delivering neutrophil subset that induces angiogenesis in transplanted hypoxic tissue. Blood 2012, 120:4653-4662

11. Lifson N, Lassa CV, Dixit PK: Relation between blood flow and morphology in islet organ of rat pancreas. Am J Physiol 1985, 249: $\mathrm{E} 43-\mathrm{E} 48$

12. Jansson L: The regulation of pancreatic islet blood flow. Diabetes Metab Rev 1994, 10:407-416
13. Bonner-Weir S, Orci L: New perspectives on the microvasculature of the islets of Langerhans in the rat. Diabetes 1982, 31:883-889

14. Peiris H, Bonder CS, Coates PT, Keating DJ, Jessup CF: The betacell/EC axis: how do islet cells talk to each other? Diabetes 2014, 63:3-11

15. Nikolova G, Jabs N, Konstantinova I, Domogatskaya A, Tryggvason K, Sorokin L, Fassler R, Gu G, Gerber HP, Ferrara N, Melton DA, Lammert E: The vascular basement membrane: a niche for insulin gene expression and Beta cell proliferation. Dev Cell 2006, 10:397-405

16. Johansson A, Lau J, Sandberg M, Borg LA, Magnusson PU, Carlsson PO: Endothelial cell signalling supports pancreatic beta cell function in the rat. Diabetologia 2009, 52:2385-2394

17. Drott CJ, Olerud J, Emanuelsson H, Christoffersson G, Carlsson PO: Sustained Beta-cell dysfunction but normalized islet mass in aged thrombospondin-1 deficient mice. PLoS One 2012, 7:e47451

18. Johansson M, Mattsson G, Andersson A, Jansson L, Carlsson PO: Islet endothelial cells and pancreatic beta-cell proliferation: studies in vitro and during pregnancy in adult rats. Endocrinology 2006, $147: 2315-2324$

19. Lammert E, Gu G, McLaughlin M, Brown D, Brekken R, Murtaugh LC, Gerber HP, Ferrara N, Melton DA: Role of VEGF-A in vascularization of pancreatic islets. Curr Biol 2003, 13: $1070-1074$

20. Reinert RB, Brissova M, Shostak A, Pan FC, Poffenberger G, Cai Q, Hundemer GL, Kantz J, Thompson CS, Dai C, McGuinness OP, Powers AC: Vascular endothelial growth factor-a and islet vascularization are necessary in developing, but not adult, pancreatic islets. Diabetes 2013, 62:4154-4164

21. Kamba T, Tam BY, Hashizume H, Haskell A, Sennino B, Mancuso MR, Norberg SM, O’Brien SM, Davis RB, Gowen LC, Anderson KD, Thurston G, Joho S, Springer ML, Kuo CJ, McDonald DM: VEGF-dependent plasticity of fenestrated capillaries in the normal adult microvasculature. Am J Physiol Heart Circ Physiol 2006, 290:H560-H576

22. Dubois B, Masure S, Hurtenbach U, Paemen L, Heremans H, van den Oord J, Sciot R, Meinhardt T, Hämmerling G, Opdenakker G, Arnold B: Resistance of young gelatinase B-deficient mice to experimental autoimmune encephalomyelitis and necrotizing tail lesions. J Clin Invest 1999, 104:1507-1515

23. Mattsson G, Jansson L, Carlsson PO: Decreased vascular density in mouse pancreatic islets after transplantation. Diabetes 2002, 51: 1362-1366

24. Weibel ER: Morphometry of the human lung: the state of the art after two decades. Bull Eur Physiopathol Respir 1979, 15:999-1013

25. Andersson A: Isolated mouse pancreatic islets in culture: effects of serum and different culture media on the insulin production of the islets. Diabetologia 1978, 14:397-404

26. Carlsson PO, Flodstrom M, Sandler S: Islet blood flow in multiple low dose streptozotocin-treated wild-type and inducible nitric oxide synthase-deficient mice. Endocrinology 2000, 141:2752-2757

27. Kampf C, Bodin B, Kallskog O, Carlsson C, Jansson L: Marked increase in white adipose tissue blood perfusion in the type 2 diabetic GK rat. Diabetes 2005, 54:2620-2627

28. Jansson L, Hellerstrom C: A rapid method of visualizing the pancreatic islets for studies of islet capillary blood flow using nonradioactive microspheres. Acta Physiol Scand 1981, 113:371-374

29. Descamps FJ, Martens E, Ballaux F, Geboes K, Opdenakker G: In vivo activation of gelatinase B/MMP-9 by trypsin in acute pancreatitis is a permissive factor in streptozotocin-induced diabetes. J Pathol 2004, 204:555-561

30. Vu TH, Shipley JM, Bergers G, Berger JE, Helms JA, Hanahan D, Shapiro SD, Senior RM, Werb Z: MMP-9/gelatinase B is a key regulator of growth plate angiogenesis and apoptosis of hypertrophic chondrocytes. Cell 1998, 93:411-422

31. Cauwe B, Martens E, Sagaert X, Dillen C, Geurts N, Li S, Mertens J, Thijs G, Van den Steen PE, Heremans H, De Vos R, Blockmans D, 
Arnold B, Opdenakker G: Deficiency of gelatinase B/MMP-9 aggravates lpr-induced lymphoproliferation and lupus-like systemic autoimmune disease. J Autoimmun 2011, 36:239-252

32. Dubois B, Arnold B, Opdenakker G: Gelatinase B deficiency impairs reproduction. J Clin Invest 2000, 106:627-628

33. Plaks V, Rinkenberger J, Dai J, Flannery M, Sund M, Kanasaki K, Ni W, Kalluri R, Werb Z: Matrix metalloproteinase-9 deficiency phenocopies features of preeclampsia and intrauterine growth restriction. Proc Natl Acad Sci U S A 2013, 110:11109-11114

34. Camp TM, Tyagi SC, Senior RM, Hayden MR, Tyagi SC: Gelatinase B(MMP-9) an apoptotic factor in diabetic transgenic mice. Diabetologia 2003, 46:1438-1445

35. Descamps FJ, Martens E, Proost P, Starckx S, Van den Steen PE, Van Damme J, Opdenakker G: Gelatinase B/matrix metalloproteinase-9 provokes cataract by cleaving lens betaB1 crystallin. FASEB J 2005, 19:29-35

36. Kowluru RA, Mohammad G, dos Santos JM, Zhong Q: Abrogation of MMP-9 gene protects against the development of retinopathy in diabetic mice by preventing mitochondrial damage. Diabetes 2011, 60:3023-3033

37. Mishra PK, Chavali V, Metreveli N, Tyagi SC: Ablation of MMP9 induces survival and differentiation of cardiac stem cells into cardiomyocytes in the heart of diabetics: a role of extracellular matrix. Can J Physiol Pharmacol 2012, 90:353-360

38. Lingwal N, Padmasekar M, Samikannu B, Bretzel RG, Preissner KT, Linn T: Inhibition of gelatinase B (matrix metalloprotease-9) activity reduces cellular inflammation and restores function of transplanted pancreatic islets. Diabetes 2012, 61:2045-2053

39. Kundu S, Pushpakumar SB, Tyagi A, Coley D, Sen U: Hydrogen sulfide deficiency and diabetic renal remodeling: role of matrix metalloproteinase-9. Am J Physiol Endocrinol Metab 2013, 304: E1365-E1378

40. Li SY, Huang PH, Yang AH, Tarng DC, Yang WC, Lin CC, Chen JW, Schmid-Schonbein G, Lin SJ: Matrix metalloproteinase-9 deficiency attenuates diabetic nephropathy by modulation of podocyte functions and dedifferentiation. Kidney Int 2014, 86:358-369

41. Mohammad G, Vandooren J, Siddiquei MM, Martens E, Abu ElAsrar AM, Opdenakker G: Functional links between gelatinase $\mathrm{B} /$ matrix metalloproteinase-9 and prominin-1/CD133 in diabetic retinal vasculopathy and neuropathy. Prog Retin Eye Res 2014, 43:76-91

42. Hu J, Van den Steen PE, Sang QX, Opdenakker G: Matrix metalloproteinase inhibitors as therapy for inflammatory and vascular diseases. Nat Rev Drug Discov 2007, 6:480-498

43. Aston-Mourney K, Zraika S, Udayasankar J, Subramanian SL, Green PS, Kahn SE, Hull RL: Matrix metalloproteinase-9 reduces islet amyloid formation by degrading islet amyloid polypeptide. J Biol Chem 2013, 288:3553-3559

44. Jackson AM, Kanak MA, Grishman EK, Chaussabel D, Levy MF, Naziruddin B: Gene expression changes in human islets exposed to type 1 diabetic serum. Islets 2012, 4:312-319

45. Du R, Lu KV, Petritsch C, Liu P, Ganss R, Passegue E, Song H, Vandenberg S, Johnson RS, Werb Z, Bergers G: HIF1alpha induces the recruitment of bone marrow-derived vascular modulatory cells to regulate tumor angiogenesis and invasion. Cancer Cell 2008, 13: 206-220

46. Ziolkowski AF, Popp SK, Freeman C, Parish CR, Simeonovic CJ: Heparan sulfate and heparanase play key roles in mouse beta cell survival and autoimmune diabetes. J Clin Invest 2012, 122: 132-141

47. D’Hoker J, De Leu N, Heremans Y, Baeyens L, Minami K, Ying C, Lavens A, Chintinne M, Stange G, Magenheim J, Swisa A, Martens G, Pipeleers D, van de Casteele M, Seino S, Keshet E, Dor Y, Heimberg H: Conditional hypovascularization and hypoxia in islets do not overtly influence adult beta-cell mass or function. Diabetes $2013,62: 4165-4173$

48. Jewell JL, Oh E, Thurmond DC: Exocytosis mechanisms underlying insulin release and glucose uptake: conserved roles for Munc18c and syntaxin 4. Am J Physiol Regul Integr Comp Physiol 2010, 298 : R517-R531

49. Handschin C, Spiegelman BM: Peroxisome proliferator-activated receptor gamma coactivator 1 coactivators, energy homeostasis, and metabolism. Endocr Rev 2006, 27:728-735

50. Ishihara H, Wang H, Drewes LR, Wollheim CB: Overexpression of monocarboxylate transporter and lactate dehydrogenase alters insulin secretory responses to pyruvate and lactate in beta cells. J Clin Invest $1999,104: 1621-1629$

51. Sekine N, Cirulli V, Regazzi R, Brown LJ, Gine E, TamaritRodriguez J, Girotti M, Marie S, MacDonald MJ, Wollheim CB, Rutter GA: Low lactate dehydrogenase and high mitochondrial glycerol phosphate dehydrogenase in pancreatic beta-cells. Potential role in nutrient sensing. J Biol Chem 1994, 269: 4895-4902

52. Paulmann N, Grohmann M, Voigt JP, Bert B, Vowinckel J, Bader M, Skelin M, Jevsek M, Fink H, Rupnik M, Walther DJ: Intracellular serotonin modulates insulin secretion from pancreatic beta-cells by protein serotonylation. PLoS Biol 2009, 7: e1000229

53. Kim H, Toyofuku Y, Lynn FC, Chak E, Uchida T, Mizukami H, Fujitani Y, Kawamori R, Miyatsuka T, Kosaka Y, Yang K, Honig G, van der Hart M, Kishimoto N, Wang J, Yagihashi S, Tecott LH, Watada H, German MS: Serotonin regulates pancreatic beta cell mass during pregnancy. Nat Med 2010, 16:804-808

54. Gebre-Medhin S, Mulder H, Pekny M, Westermark G, Tornell J, Westermark P, Sundler F, Ahren B, Betsholtz C: Increased insulin secretion and glucose tolerance in mice lacking islet amyloid polypeptide (amylin). Biochem Biophys Res Commun 1998, 250: 271-277

55. Carlsson PO, Karlsson E, Mulder H, Gebre-Medhin S: Unaltered pancreatic islet blood perfusion in islet amyloid polypeptide-deficient mice. Eur J Endocrinol 2002, 146:107-112

56. Liu Z, Zhou X, Shapiro SD, Shipley JM, Twining SS, Diaz LA, Senior RM, Werb Z: The serpin alpha1-proteinase inhibitor is a critical substrate for gelatinase B/MMP-9 in vivo. Cell 2000, 102: 647-655

57. McKee CM, Xu D, Kessler BM, Muschel RJ: Proteomic analysis reveals a proteolytic feedback loop in murine seminal fluid. Prostate 2013, 73:1427-1440

58. Gu Z, Cui J, Brown S, Fridman R, Mobashery S, Strongin AY, Lipton SA: A highly specific inhibitor of matrix metalloproteinase-9 rescues laminin from proteolysis and neurons from apoptosis in transient focal cerebral ischemia. J Neurosci 2005, 25:6401-6408

59. Zamilpa R, Lopez EF, Chiao YA, Dai Q, Escobar GP, Hakala K, Weintraub ST, Lindsey ML: Proteomic analysis identifies in vivo candidate matrix metalloproteinase- 9 substrates in the left ventricle post-myocardial infarction. Proteomics 2010, 10:2214-2223

60. Prudova A, auf dem Keller U, Butler GS, Overall CM: Multiplex N-terminome analysis of MMP-2 and MMP-9 substrate degradomes by iTRAQ-TAILS quantitative proteomics. Mol Cell Proteomics 2010, 9:894-911

61. Jansson L, Hellerstrom C: Stimulation by glucose of the blood flow to the pancreatic islets of the rat. Diabetologia 1983, 25: $45-50$

62. Carlsson PO, Olsson R, Kallskog O, Bodin B, Andersson A, Jansson L: Glucose-induced islet blood flow increase in rats: interaction between nervous and metabolic mediators. Am J Physiol Endocrinol Metab 2002, 283:E457-E464

63. Descamps FJ, Van den Steen PE, Martens E, Ballaux F, Geboes K, Opdenakker G: Gelatinase B is diabetogenic in acute and chronic pancreatitis by cleaving insulin. FASEB J 2003, 17:887-889

64. Jacqueminet S, Ben Abdesselam O, Chapman MJ, Nicolay $\mathrm{N}$, Foglietti MJ, Grimaldi A, Beaudeux JL: Elevated circulating levels of matrix metalloproteinase-9 in type 1 diabetic patients with and without retinopathy. Clin Chim Acta 2006, 367: 103-107 